\title{
CINEMA 4D DALAM PIPELINE PRODUKSI SERIAL ANIMASI
}

\author{
Ardiyansah \\ Jurusan Desain Komunikasi Visual, Fakultas Komunikasi dan Multimedia, Universitas Bina Nusantara \\ Jl. KH. Syahdan 9, Kemanggisan, Jakarta Barat \\ sah@binus.ac.id
}

\begin{abstract}
Cinema $4 D$ is best known as software that is efficient in render time. This is very beneficial especially for those who engaged in animated projects with tight deadlines and require work time efficiency, such as serial project. In addition to time, in the animated series production pipeline also generally require various items of work that involves a lot of resources implemented in parallel. This is to avoid delays to the overall project progress whenever a work item suffers setback due to any reason. Cinema 4D as a tool, allowing a project carried out with the most efficient method in accordance with needs, and flexibility that is the appeal of Cinema $4 D$ as well as strength in the context of the animated series production.
\end{abstract}

Keywords: Cinema 4D, Animation, Serial, Pipeline

\begin{abstract}
ABSTRAK
Cinema 4D dikenal sebagai software yang memiliki keunggulan pada efisiensi render time. Hal ini sangat menguntungkan terutama bagi mereka yang berkutat dalam proyek-proyek animasi dengan tenggat ketat dan memerlukan efisiensi waktu kerja, seperti misalnya proyek serial. Selain waktu, dalam pipeline produksi serial animasi umumnya juga menuntut berbagai item pekerjaan yang melibatkan banyak sumber daya bisa dilaksanakan secara paralel. Hal ini untuk menghindari penundaan terhadap kelangsungan proyek secara keseluruhan jika salah satu item pekerjaan mengalami kemunduran karena suatu sebab. Cinema 4D sebagai tool, memungkinkan sebuah proyek dilaksanakan dengan metode paling efisien sesuai dengan kebutuhan, dan fleksibilitas inilah yang menjadi daya tarik sekaligus kekuatan Cinema $4 D$ dalam konteks produksi serial animasi.
\end{abstract}

Kata kunci: Cinema 4D, Animasi, Serial, Pipeline 


\section{PENDAHULUAN}

Seperti lazimnya proyek animasi, dalam serial terdapat 3 tahapan utama yang meliputi: 1) Pre Production; 2) Production; dan 3) Post Production. Ketiga tahap tersebut mempunyai bobot dan kapasitasnya masing-masing yang turut berperan dalam membentuk hasil akhir proyek tersebut.

Pre Production diantaranya memberikan kontribusi berupa ide cerita, script, storyboard, hingga animatic. Pada tahap ini juga telah ditetapkan hal-hal yang nantinya akan dilakukan atau berkaitan dengan proses produksi, misalnya jumlah tenaga yang dipakai, ragam keahlian yang dibutuhkan, termasuk tool (baca: software) yang digunakan untuk mendukung produksi. Hal ini menjadi penting karena kesalahan dalam menentukan software akan berakibat pada molornya jadwal produksi hingga berlarut-larut bahkan mengancam kelangsungan proyek itu sendiri.

Dalam hal menentukan tool yang dipakai, tentu tidak hanya membicarakan jenis software-nya saja. Mengingat dalam sebuah proyek serial animasi melibatkan berbagai jenis pekerjaan, berarti kebutuhan software juga beragam, maka yang tak boleh luput dari perhatian adalah tentang "komunikasi" lintas software untuk mendukung efisiensi yang dimaksud. Semakin banyak software yang dipergunakan, semakin beresiko pada komunikasi antar software tersebut.

Salah satu kekuatan Cinema 4D adalah kemampuan meng-integrasikan berbagai kebutuhan penciptaan animasi didalam satu paket yang terorganisir sehingga memudahkan proses produksi dalam satu software. Dengan Cinema 4D memungkinkan proses produksi dilakukan mulai dari modelling, rigging, texturing, animating, hingga rendering tanpa melibatkan atau memerlukan tool dari luar.

\section{METODE}

Penelitian dilakukan dengan mengumpulkan berbagai informasi dan literatur untuk mendukung eksperimen terkait. Eksperimen meliputi proses (termasuk) trial and error keseluruhan rangkaian produksi serial animasi dengan menggunakan Cinema 4D yang hasilnya diseleksi dan disintesakan menjadi karya tulis.

\section{HASIL DAN PEMBAHASAN}

Sebelum memulai pembahasan tentang serial animasi, ada baiknya mengenal karakteristik serial animasi ditinjau dari sisi produksi. Hal yang perlu dipahami, produksi serial animasi dilaksanakan dalam tenggat yang relatif sangat ketat, apalagi bagi serial yang telah tayang, tim produksi harus kejar-kejaran dengan waktu tayang, sehingga tim dituntut untuk bekerja se-efisien mungkin dan sesedikit mungkin melakukan kesalahan.

Seperti yang telah disinggung sebelumnya, terdapat 3 tahapan utama untuk memproduksi serial animasi, dimana masing-masing tahap membutuhkan ketelitian dan pengawasan agar tidak sampai terjadi penundaan di satu bagian yang mengakibatkan penundaan atau keterlambatan proyek secara keseluruhan. 3 tahap itu meliputi:

\section{Pre Production}

Pre Production adalah istilah umum pada proses produksi yang muncul setelah inisiatif awal/ide sebagai bentuk perencanaan dan persiapan sebelum memasuki lingkup pekerjaan yang bersifat teknis. Tahap ini mencakup penjadwalan, penulisan naskah, dan pembuatan storyboard. 


\section{Production}

Tahap ini mencakup segala proses untuk merealisasikan apa yang sebelumnya ingin dicapai pada tahap Pre Production. Dalam konteks serial animasi, tahapan ini meliputi modelling, rigging, texturing, animating dan rendering.

\section{Post Production}

Tahap ini merupakan proses penggabungan semua materi hasil proses sebelumnya (Production) yang kemudian diolah, dikemas sehingga kemudian layak untuk didistribusikan. Yang termasuk dalam proses Post Production diantaranya: editing, compositing, color grading, dan sebagainya.

Tulisan ini tidak akan membahas secara rinci pipeline dalam sebuah proyek serial animasi, tetapi hanya pada tahap "Production" serta peran dan fungsi yang melibatkan Cinema 4D.

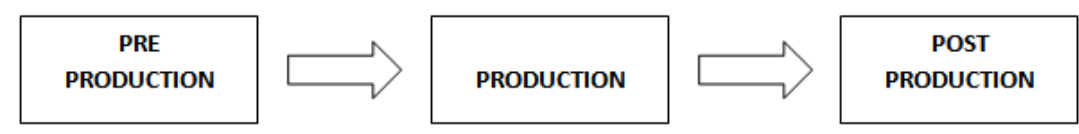

Gambar 1Diagram proses produksi animasi secara umum

Tiap tahap dalam proses produksi serial animasi harus dilakukan dengan mengikuti struktur seperti yang sudah ditetapkan dalam pipeline atau perencanaan produksi. Hal ini mengingat banyak proses yang saling terkait sehingga tidak memungkinkan dilakukan secara sporadis atau terpisahpisah. Beberapa proses bahkan baru bisa dilakukan jika proses yang lain telah selesai. Artinya, jika terjadi keterlambatan atau masalah apapun pada sebuah proses bisa mengancam kelangsungan keseluruhan proyek. Setidaknya akan berpengaruh pada schedule. berikut:

Dalam sebuah proyek serial animasi (3D), secara umum pipeline bisa digambarkan sebagai

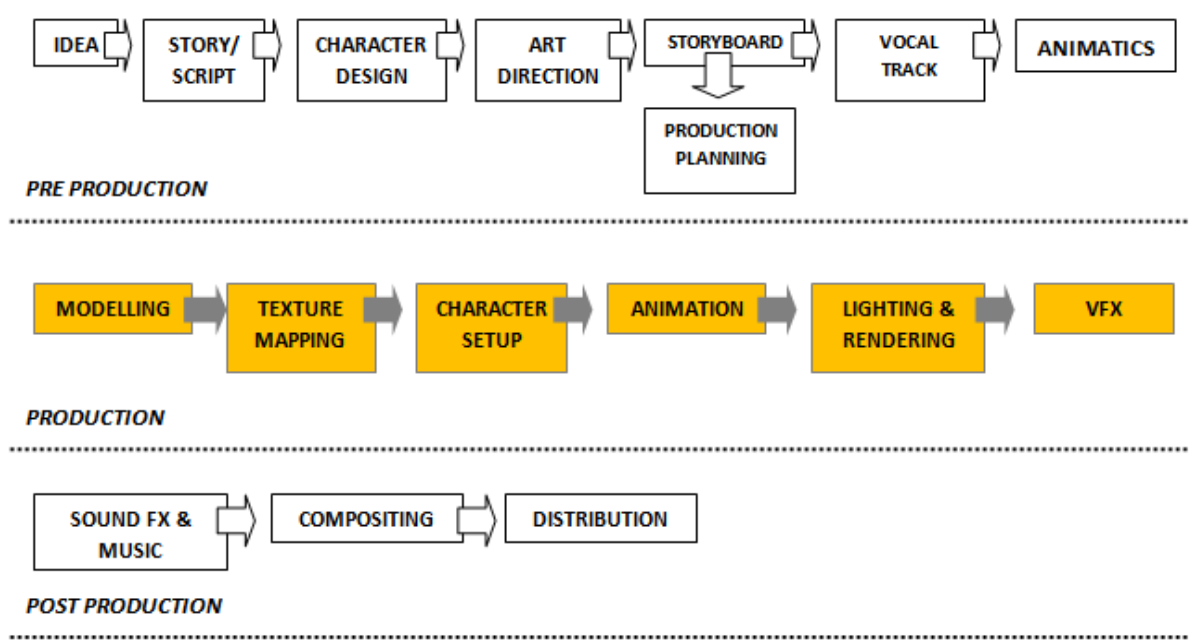

Gambar 2 Pipeline Produksi Animasi

Dari hasil breakdown pipeline produksi animasi diatas, selanjutnya kita akan membahas peran Cinema 4D, terutama pada tahap Production. 


\section{Modelling}

Setelah di Pre Production dilakukan berbagai persiapan yang salah satunya menghasilkan character, proses selanjutnya adalah mevisualisasikan karakter tersebut kedalam format 3 dimensi. Disinilah dilakukan proses modelling.

Seperti halnya software permodelan 3D lainnya, Cinema 4D dilengkapi dengan tool yang yang handy untuk mengolah dan membentuk figur 3 dimensional sesuai hasil perencanaan. Tersedia 3 pilihan untuk mengatur point (titik), edge (garis), dan polygon (bidang) yang bisa dipilih sesuai kebutuhan hanya dengan menekan tombol enter.

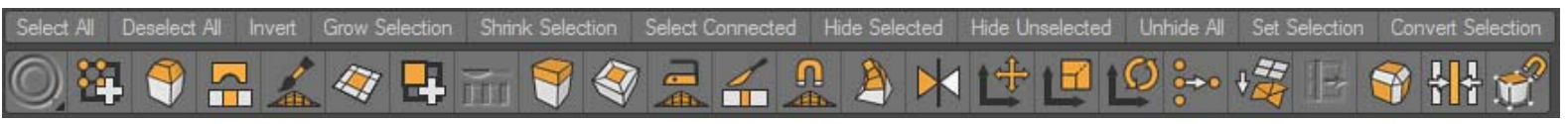

Gambar 3 Berbagai Macam Modelling Tools dalam Cinema 4D

Fitur Cinema 4D terkait modelling antara lain, Knife (memotong objek), Iron (merapikan objek), Magnet (mengacak bentuk objek), Create Polygon (membuat poligon/ bidang baru), Brush, Matrix Extrude, dan lain-lain.

\section{Texture Mapping}

Salah satu fitur andalan Cinema 4D adalah BodyPaint. Fitur ini memberikan kemudahan dalam memberikan texture bahkan pada objek paling rumit sekalipun. Konsepnya, texturing dilakukan pada bidang 3D yang diproyeksikan sebagai objek planar sehingga seolah-olah objek 3D tersebut adalah kanvas datars yang siap diisi texture apa saja.

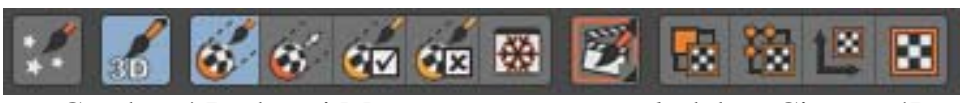

Gambar 4 Berbagai Macam Texturing Tools dalam Cinema 4D

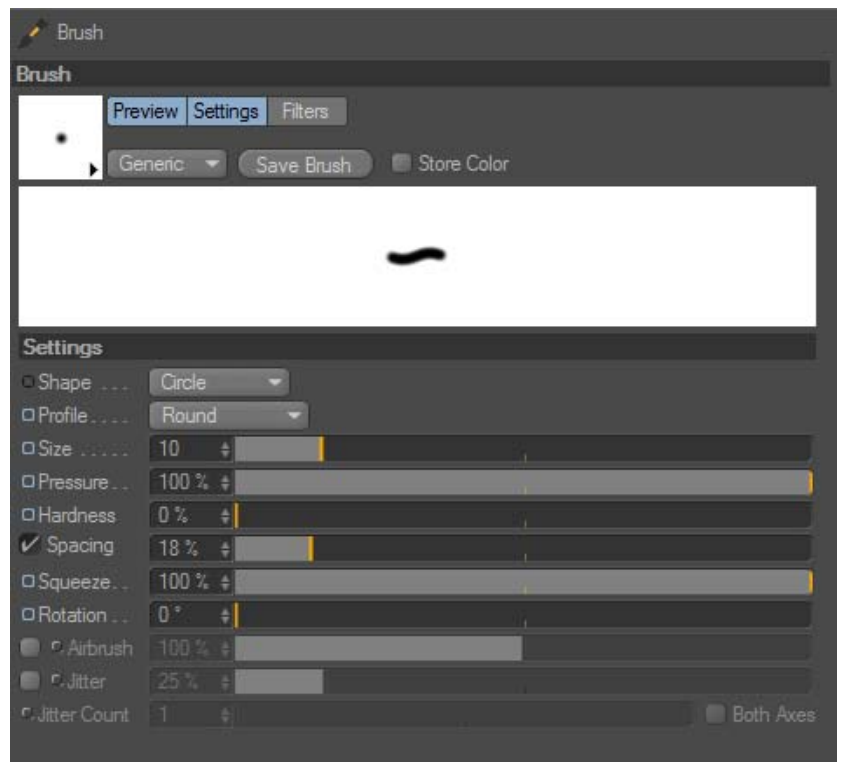

Gambar 5 Berbagai jenis pengaturan brush dalam Cinema 4D 


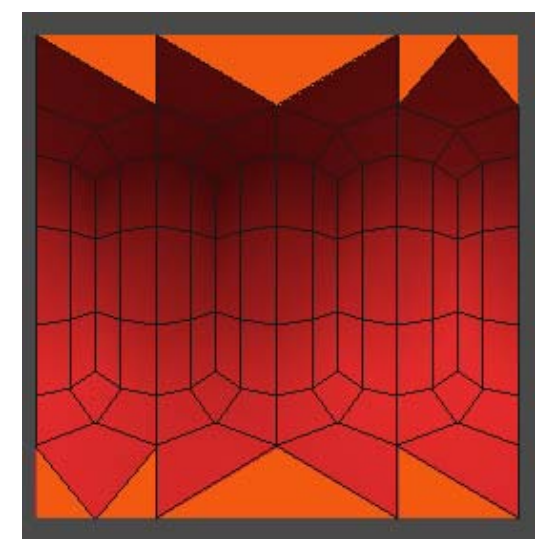

Gambar 6 Sampel pengaturan UV Projection Map

Fitur Cinema 4D terkait texture mapping diantaranya, BodyPaint 3D Paint (melakukan texturing langsung pada objek 3D), BodyPaint UV Edit (melakukan pengaturan UV), Optimal Mapping, dan Relax UV.

\section{Character Setup}

Setelah karakter selesai dimodel dan dan ditekstur, langkah selanjutnya adalah menyiapkan karakter sampai siap dianimasikan. Hal-hal yang terkait character setup diantaranya adalah, Joint Tool (untuk mengatur pertulangan karakter - lihat Gambar 7), Weight Tool (mengatur area yang terpengaruh oleh tulang/ joint), Morph Tag (mengatur ekspresi wajah), dan lain-lain.

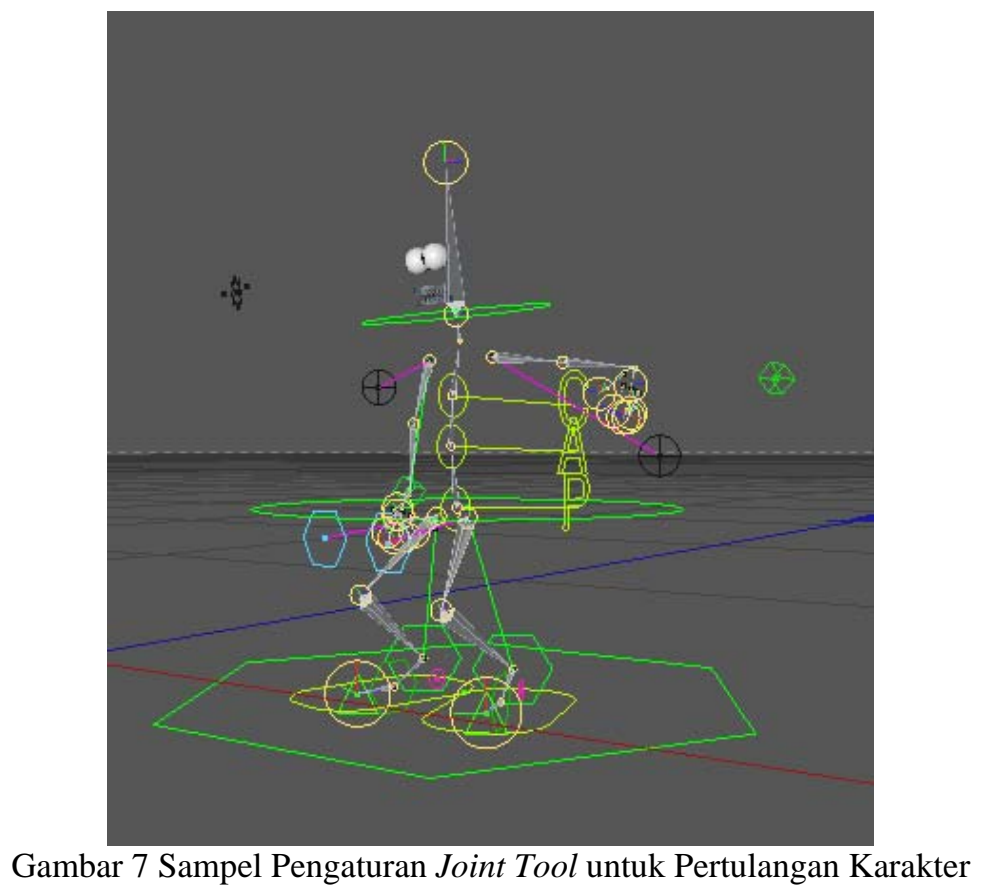

\section{Animation}

Animasi bisa dilakukan setelah karakter benar-benar siap. Dalam konteks ini secara teknis sudah benar-benar final dan sudah diujicobakan sehingga tidak ada error atau kemungkinan gerakan yang menyebabkan kerusakan bentuk karakter seperti bidang yang saling tembus (overlap) dan keriput. 
Fitur yang menjadi andalan dalam animasi di Cinema 4D adalah Motion System yang memuat berbagai tool untuk memudahkan dan mempercepat proses animasi (Gambar 8).

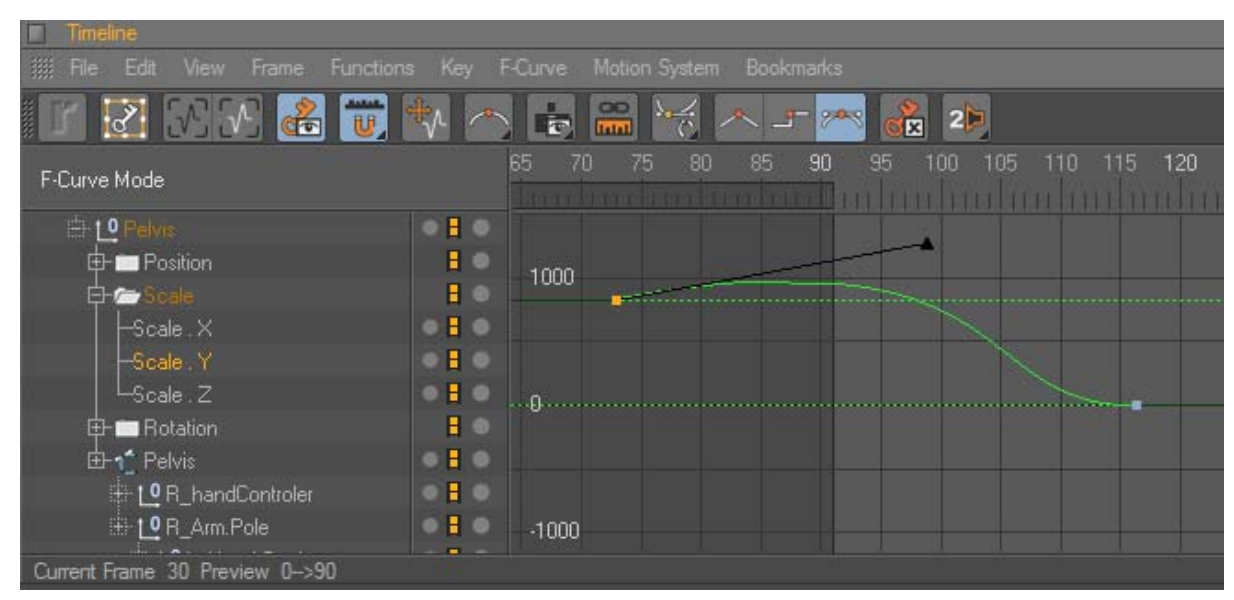

Gambar 8 Interface timeline untuk animasi dalam Cinema 4D

\section{Lighting \& Rendering}

Setelah semua proses animasi berjalan lancar, maka proses selanjutnya adalah memberikan pencahayaan yang tepat sesuai dengan kebutuhan. Lighting sangat berpengaruh untuk menentukan hasil akhir dari proyek animasi yang dikerjakan. Selain memperindah visual, lighting juga berperan membentuk mood.

Beberapa hal terkait lighting \& rendering di Cinema 4D antara lain, Light (berbagai jenis lampu/ pencahayaan), Shadow (berbagai jenis dan intensitas bayangan), Sky, HDRI, Ambient Occlusion, dan Global Illumination (Gambar 9).

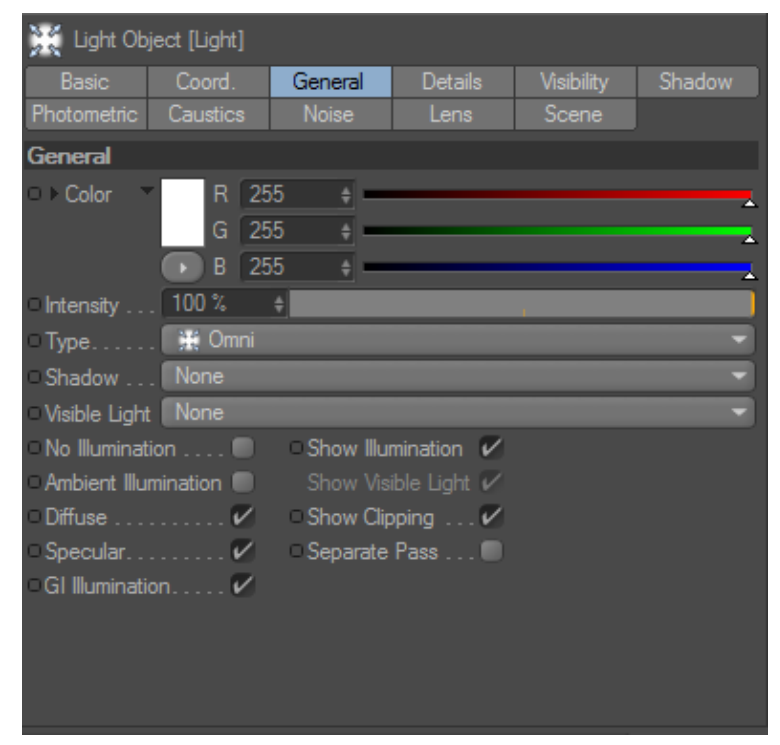

Gambar 9 Berbagai Item Pengaturan Lighting dalam Cinema 4D 


\section{Visual Effect}

Cinema 4D memiliki beberapa fitur andalan terkait dengan visual effect, tetapi yang paling menonjol adalah MoGraph yang mampu meng-handle animasi multiple object secara mudah dan efisien (lihat Gambar 10).

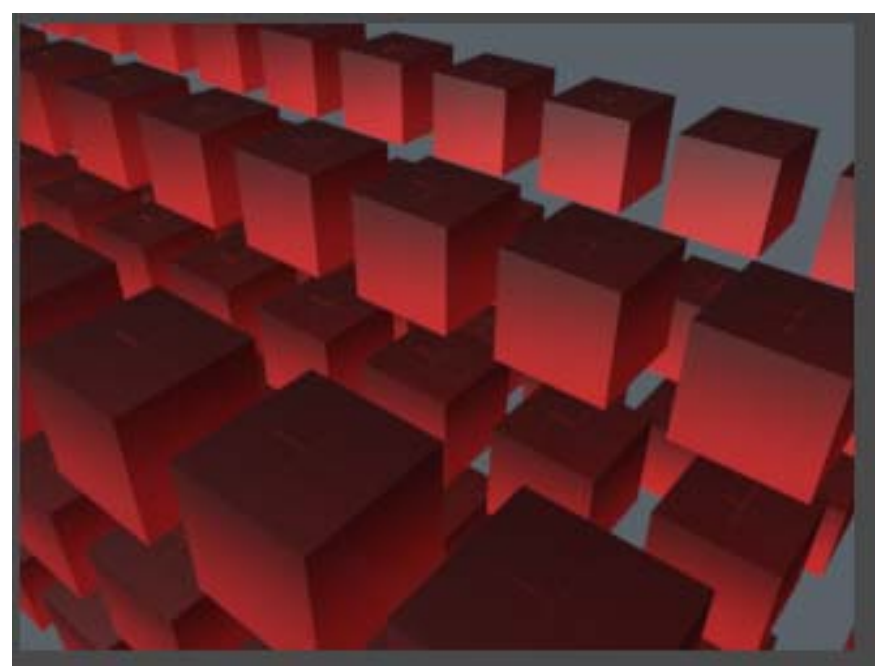

Gambar 10 Salah satu contoh aplikasi MoGraph

Keistimewaan Cinema 4D tidak semata pada tools atau fiturnya. Tetapi secara keseluruhan, fitur-fitur tersebut bisa saling bersinergi menghasilkan sebuah sistem yang praktis. Misal, jika selama ini kebutuhan texturing lebih banyak dilakukan dengan menggunakan Adobe Photoshop, maka dengan menguasai BodyPaint, segala kebutuhan texturing bisa dilakukan tanpa perlu pindah aplikasi.

Dalam Cinema 4D memungkinkan kita bekerja secara fleksibel. Misalnya, setelah model/ karakter diselesaikan, kita bisa mendistribusikan pekerjaan texturing dan weighting (mengatur pertulangan) kepada orang yang berbeda dan dikerjakan secara paralel. Untuk menggabungkannya, kita hanya tinggal meng-copy tag (semacam modifier), dan hal ini jelas telah menghemat waktu daripada harus menunggu satu pekerjaan selesai baru kemudian melanjutkan pekerjaan lainnya.

Render Time juga menjadi keunggulan Cinema 4D. Dengan kualitas visual yang setara, Cinema 4D bisa membukukan waktu render yang jauh lebih cepat daripada aplikasi lain. Jika dalam satu frame kita bisa menghemat 10 detik. Bayangkan berapa banyak waktu render yang kita simpan jika kita membuat 15 menit-20 menit serial animasi.

\section{PENUTUP}

Mengerjakan serial animasi, kita dihadapkan pada banyak sekali batasan. Diantaranya adalah waktu. Untuk mengakali hal tersebut dibutuhkan suatu alternatif yang memungkinkan animasi bisa dibuat secara lebih efisien. Cinema 4D telah terbukti sebagai aplikasi yang mampu menghasilkan kualitas render prima dengan render time yang sangat efisien. Sayangnya, Cinema 4D belum banyak dipakai untuk kepentingan animasi organik, apalagi dalam format serial dengan durasi yang relatif panjang. Dengan tulisan ini diharapkan dunia animasi memiliki lebih banyak alternatif untuk menghasilkan karya-karya berkualitas dan bisa dikerjakan secara efisien 


\section{DAFTAR PUSTAKA}

Sarris, N., \& Strintzis, M. G. (2005). 3d Modeling and Animation : Synthesis and Analysis Techniques for the Human Body. London: IRM Press.

Scott, L. M., \& Batra R. (2003). Persuasive Imagery : A Consumer Response Perspective. London: Lawrence Erlbaum Associates.

Watkins, A. (2001). 3D Animation: From Models to Movies. Massachusetts: Charles River Media, Inc. 